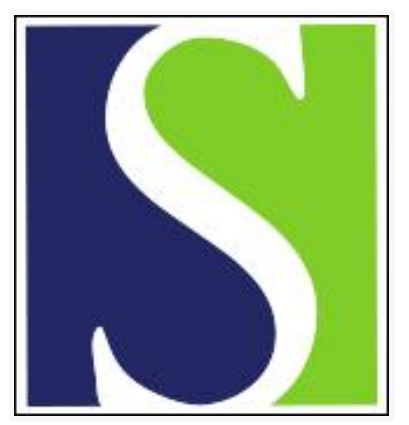

Scand J Work Environ Health 2003;29(3):230-238

https://doi.org/10.5271/sjweh.726

Issue date: Jun 2003

Endocrine and immunologic markers in manganese alloy production workers

by Ellingsen DG, Haug E, Gaarder PI, Bast-Pettersen R, Thomassen $Y$

Affiliation: National Institute of Occupational Health, PO Box 8149 Dep, N-0033 Oslo, Norway. dag.ellingsen@stami.no

Refers to the following text of the Journal: 1997;23(5):334-341

Key terms: endocrine; immunologic marker; manganese; manganese alloy production worker; prolactin; smoking habit; soluble inhalable manganese

This article in PubMed: www.ncbi.nlm.nih.gov/pubmed/12828393 


\title{
Endocrine and immunologic markers in manganese alloy production workers
}

\author{
by Dag G日lingsen, MD, ${ }^{1}$ Egil Haug, MD, ${ }^{2}$ Per I Gaarder, MD, ${ }^{3}$ Rita Bast-Pettersen, PsyD, ${ }^{1}$ \\ Yngvar Thomassen, MSc ${ }^{1}$
}

\begin{abstract}
Elingsen DG, Haug E, Gaarder PI, Bast-Pettersen R, Thomassen Y. Endocrine and immunologic markers in manganese alloy production workers. Scand J Work Environ Health 2003;29(3):230-238.

Objectives The aim of this study was to investigate selected hormones and immunologic markers in manganese alloy production workers with current and long-term manganese exposure.

Methods One hundred randomly selected male workers exposed to manganese were compared with 100 male referents (matched for age) from similar process industries in a cross-sectional design.

Results The geometric mean of the exposed workers' urinary manganese concentration was 0.9 (range 0.1126.3) nmol/mmol creatinine (Cr) versus 0.4 (range $0.1-13.1$ ) $\mathrm{nmol} / \mathrm{mmol} \mathrm{Cr}$ for the referents. The mean duration of exposure to manganese was 20.0 (range 2.1-41.0) years. The geometric mean of the prolactin serum concentration was higher for the exposed subjects than for the referents ( 229 versus $197 \mathrm{mIE} / \mathrm{l}, \mathrm{P}=0.06)$. Serum prolactin was associated with current exposure to "soluble inhalable manganese", duration of exposure, and smoking habits. The subjects with the longest duration of exposure to manganese or the highest current exposure to "soluble inhalable manganese" had a statistically significantly higher serum prolactin concentration than the referents. The smokers had a lower serum prolactin concentration than the nonsmokers. The concentrations of the measured immunologic markers were similar in the groups.

Conclusions The study indicates that manganese exposure can increase the serum prolactin concentration. Both duration and current level of exposure are related to the slight increase, which also appears to be modified by current smoking habits. The serum prolactin concentrations were generally within the reference limits of the laboratory and thus not suitable as an exposure marker at these exposure levels.
\end{abstract}

Key terms manganese, prolactin, smoking habits, "soluble inhalable manganese".

The mechanisms for manganese $(\mathrm{Mn})$ toxicity in the human central nervous system (CNS) are not fully understood, but a selectivity for dopaminergic neurons is apparent (1). Prolactin secretion is under tonic hypothalamic inhibition by dopamine produced by tuberoinfundibular dopaminergic neurons. Dopamine acts by binding to $\mathrm{D}_{2}$ receptors on the lactotrophs, thereby inhibiting both the release and the synthesis of prolactin (2). As dopamine release into the portal veins of the hypophyseal stalk and the binding to $\mathrm{D}_{2}$ receptors take place in regions localized outside the blood-brain barrier, it is imaginable that prolactin production and secretion may constitute sensitive targets for manganese toxicity.
The intraventricular administration of manganese to rats resulted in increased serum prolactin concentrations (3). There are few studies of the serum prolactin levels in manganese-exposed humans. Increased serum prolactin concentrations have been reported for 14 manganese alloy production workers (4). Increased serum prolactin concentrations were also reported in a subsequent study of 31 manganese alloy production workers, and associations between serum prolactin levels and manganese concentrations in whole blood (B-Mn) and urine (U-Mn) were suggested (5). However, no significant increase in serum prolactin levels was found among 92 dry alkaline battery workers (6).

1 National Institute of Occupational Health, Oslo, Norway.

2 Hormone Laboratory, Aker University Hospital, Oslo, Norway.

3 Department of Immunology and Transfusion Medicine, Ullevål University Hospital, Oslo, Norway.

Reprint requests to: Dr Dag G Ellingsen, National Institute of Occupational Health, PO Box 8149 Dep, N-0033 Oslo, Norway. [E-mail: @dag.ellingsen@stami.no] 
The main biological effect of prolactin in humans is the stimulation of milk synthesis and secretion. Physiological hyperprolactinemia during lactation and pregnancy and pathological hyperprolactinemia are associated with hypothalamic pituitary-gonadal axis suppression, probably resulting from prolactin-induced inhibition of the pulsatile secretion of gonadotropin-releasing hormone (GRH) (2). Inhibition of GRH could be compatible with the high prevalence of impotency in the prodromal phase of manganism reported for manganese miners (7).

Prolactin has been suggested also to have a modulating role on the function of the immune system (810). Prolactin receptors are prevalent on the surface of several classes of immunocompetent human cells (10). Human lymphocytes and thymocytes also produce prolactin (11). There is evidence of associations between high serum concentrations of prolactin and an increased incidence of autoimmune disorders such as thyroiditis, arthritis, and systemic lupus erythematosus in humans and in animal models (10).

Manganese (II) injected intraperitoneally into mice affected T-cell proliferation and depressed the development of cells producing certain antibodies (12). Increased mouse natural killer-cell activity was found after the intramuscular administration of manganese (II) $(13,14)$, and an increased concentration of serum interferon was observed $(13,15)$. In contrast, one in vitro study showed a reduced cell production of interferon and increased virus growth in cells exposed to manganese (16).

The aim of our study was to investigate serum concentrations of prolactin and other hormones related to sexual functions in a population occupationally exposed to manganese. Some markers of immune system functioning that have been associated with hyperprolactinemia or with manganese exposure in animals were also studied.

\section{Subjects and methods}

\section{Study design and subjects}

Only men who had been exposed to manganese for at least 1 year in contaminated areas in the three manganese-alloy-producing plants under study, and exposed at the time of the examinations, were eligible for inclusion in this cross-sectional study. Administrative personnel were not invited to participate. The study aimed at investigating 100 exposed subjects, who were randomly selected from the eligible subjects. To fulfill this aim, 110 subjects were invited to participate. Ten subjects declined participation (participation rate among the exposed $90.9 \%$ ).
The total eligible population comprised 547 subjects, the breakdown per plant being $48.4 \%, 28.3 \%$, and $23.2 \%$. The representations from each plant were $49 \%$, $26 \%$, and $25 \%$ among the 100 studied workers. The selection procedure was carried out within each plant, based on the selection of each fourth individual from an alphabetical list of eligible subjects. The place used to start in the alphabet varied between the plants and was decided without any a priori knowledge of the subjects.

The study design was based on pairwise matching of one exposed subject with one referent for age. The referents, recruited from a silicon-metal-producing plant and a plant producing titanium dioxide and pig iron, both located in the same geographic region, had work conditions and occupations similar to those of the exposed workers. The subject with the closest date of birth to the exposed subject to be matched was chosen as the referent. To match the 100 exposed workers, 110 potential referents were invited. By coincidence, also 10 subjects declined participation, yielding a participation rate of $90.9 \%$ among the referents as well.

Subjects with known alcoholism or current or previous serious CNS diseases unrelated to manganese exposure were excluded from participation. Likewise, subjects who had previously been employed in occupations involving exposure to organic solvents ( $>5$ years) or who had been exposed to lead or mercury in occupations using these elements ( $>1$ year) were not considered for participation in the study. Exclusion criteria were identical for the exposed subjects and the referents. Exclusion was done prior to the invitation of the subjects. The main cause of exclusion among the exposed subjects was alcohol abuse $(\mathrm{N}=17)$, whereas two subjects were excluded due to serious CNS diseases (vascular).

All the examinations, including a structured interview emphasizing the occupational and medical history, sociodemographic background, and current alcohol consumption (17), were carried out at the local occupational health clinics. Table 1 shows the background data. Informed written consent was obtained from all the participants. The study protocol was approved by the regional ethics committee for medical research.

\section{Exposure assessment}

The current individual exposure of each worker to airborne manganese was characterized by personal fullshift sampling. The sampling period was 3 days closely before or after the day of the blood and urine sample collection. IOM (Institute of Occupational Medicine) personal inhalable aerosol samplers (SKC Inc, PA, USA) (airflow $2 \mathrm{l} / \mathrm{min}$ ) and Casella cyclones (Casella, London, England) (airflow $2.21 / \mathrm{min}$ ) were used for the 
Table 1. Background data for the 100 men exposed to manganese and the 100 referents.

\begin{tabular}{|c|c|c|c|c|c|c|c|c|c|c|}
\hline \multirow[t]{3}{*}{ Group } & \multirow{2}{*}{\multicolumn{2}{|c|}{ Age (years) }} & \multirow{3}{*}{$\begin{array}{l}\text { Shift } \\
\text { workers (\%) }\end{array}$} & \multirow{2}{*}{\multicolumn{2}{|c|}{$\begin{array}{l}\text { Alcohol consumption } \\
\text { (I/year) }\end{array}$}} & \multicolumn{3}{|c|}{ Smoking } & \multirow{2}{*}{\multicolumn{2}{|c|}{$\begin{array}{l}\text { Tobacco consumption } \\
\text { of smokers ( } \mathrm{g} / \text { week) }\end{array}$}} \\
\hline & & & & & & \multirow{2}{*}{$\begin{array}{c}\text { Smokers } \\
(\%)\end{array}$} & \multirow{2}{*}{$\begin{array}{l}\text { Ex-smokers } \\
(\%)\end{array}$} & \multirow{2}{*}{$\begin{array}{l}\text { Never smokers } \\
(\%)\end{array}$} & & \\
\hline & Mean & Range & & Mean & Range & & & & Mean & Range \\
\hline Exposed & 44.2 & $27.6-61.9$ & 42 & 3.9 & $0-24.9$ & 50 & 27 & 23 & 80 & $1-225$ \\
\hline Referents & 44.2 & $27.7-61.4$ & 50 & 3.3 & $0-15.9$ & 45 & 27 & 28 & 91 & $1-225$ \\
\hline
\end{tabular}

collection of the inhalable and the respirable aerosol fractions, respectively.

In all, 265 samples of the inhalable aerosol fraction were collected for the 100 exposed subjects. Manganese in the respirable aerosol fraction was measured for 59 subjects only (167 samples). A chemical leaching procedure was used to speciate manganese in 199 of the collected inhalable aerosol samples (97 subjects) and in 150 samples (53 subjects) of the respirable aerosol. The following components were quantified: (i) manganese (Mn) dissolved in 0.01 $\mathrm{M}$ ammonium acetate; (ii) $\mathrm{Mn}^{0}$ and $\mathrm{Mn}^{2+}$ [Mn metal, ferromanganese, manganese oxide and the $\mathrm{Mn}^{2+}$ part of the mixed manganese (II, III) oxide], (iii) $\mathrm{Mn}^{3+}$ and $\mathrm{Mn}^{4+}$ [the undissolved $\mathrm{Mn}^{3+}$ part of manganese (II, III) oxide, manganese (III) oxide and manganese dioxide], (iv) "insoluble" manganese digested in aqua regia/hydrofluoric acid (silicomanganese). A Perkin-Elmer Optima (model 3000) inductively coupled plasma atomic emission spectrometer (Perkin-Elmer, Norwalk, CT, USA) was used for all the measurements.

As the fourth set of components was only soluble in strong acids in the presence of hydrofluoric acid, they were defined as "insoluble". The other components were more easily chemically soluble, and components $1+2+3$ were therefore defined as "soluble". All the dose estimates were based on individually collected samples, and they represent the mean value of the available samples for each subject (generally two or three samples for each subject). Extensive details on sampling, speciation, and day-to-day variations in exposure have been presented elsewhere $(18,19)$.

\section{Laboratory measurements}

Sampling. The subjects were instructed to bring a firstvoided morning urine sample in $25-\mathrm{ml}$ NUNC ${ }^{\circledR}$ containers (Nalge Nunc International, Denmark) from the day of the examination for the measurement of trace elements. The urine was voided at home to prevent external contamination of the samples. Blood specimens were obtained from the cubital vein. Heparinized whole blood was collected for the measurement of trace elements in 10-ml Venoject ${ }^{\circledR}$ tubes (Terumo Corporation, Belgium). Blood specimens for the determination of hormones and the immunologic markers were collected in 10-ml Vacuette ${ }^{\circledR}$ tubes (Greiner Labortechnik, Austria). One milliliter of serum was pipetted into $\mathrm{NUNC}^{\circledR}$ cryotubes after centrifugation for 10 minutes at $1500 \mathrm{~g}$. All the biological samples were stored at $-20^{\circ} \mathrm{C}$ until the analysis. The blood samples were collected between 0800 and 0900 in the morning to reduce the impact of diurnal variations on the measured markers.

Immunologic assays. Antinuclear antibodies (ANA) and antibodies to thyroid peroxidase (anti-TPO) were measured by DIASTAT ELISA kits from Shield (Dundee, Scotland). Serum levels of interferon $\gamma($ IFN- $\gamma)$ and interleukin- 2 receptor $\alpha$ (IL-2R $\alpha$ ) were determined by ELISA kits from R\&D Systems (Abingdon, UK), following the manufacturers' instructions.

Hormone assays. Serum levels of prolactin, luteinizing hormone (LH), and follicle-stimulating hormone (FSH) were measured by immunofluorometric assays (IFMA) using kits supplied by Wallac Oy (Finland). The intraassay and interassay coefficients of variations were $1-4 \%$ and $2-4 \%$, respectively. Testosterone and sex hormone binding globulin (SHBG) were measured in serum by radioimmunoassays (RIA) using kits supplied by Orion Diagnostica (Finland). The intraassay and interassay coefficients of variation were $3-6 \%$ and $7-12 \%$, respectively.

\section{Measurements of manganese in urine and whole blood.} For the measurement of B-Mn, $2.5 \mathrm{ml}$ of ultrapure $65 \%$ nitric acid was added to $2 \mathrm{ml}$ of whole blood in a polypropylene digestion tube. The tube was heated to $95^{\circ} \mathrm{C}$ for 1 hour. After being cooled to room temperature, the sample was diluted to volume $(13.7 \mathrm{ml})$. Urine was diluted $1: 1$ with $0.5 \%$ nitric acid. The solutions were analyzed for manganese by electrothermal atomic absorption spectrophotometry (EAAS) using a Perkin-Elmer SIMAA 6000 system (Perkin-Elmer, Norwalk, USA), calibrated with matched standard solutions of urine and whole blood.

Seronorm human urine (batch 4043125) and whole blood (batches 404107 and 404108) reference materials (Sero Ltd, Asker, Norway) were used to assess the accuracy and reproducibility. U-Mn and B-Mn were measured in these materials with a day-to-day variation 
of $6.5 \%$ (for 4043125 ), $3.5 \%$ (for 404107 ), and $5.0 \%$ (for 404108), respectively. The results of the measurements and the values recommended by the producer were $9 \mu \mathrm{g} / \mathrm{l}$ (recommended) and 8.2 (SD 0.3) $\mu \mathrm{g} / \mathrm{l}$ (measured, $\mathrm{N}=21$ ) for $\mathrm{B}-\mathrm{Mn}$ in 404107, $13 \mu \mathrm{g} / \mathrm{l}$ (recommended) and 12.0 (SD 0.6) $\mu \mathrm{g} / \mathrm{l}$ (measured, $\mathrm{N}=22$ ) for B-Mn in 404108, and $13 \mu \mathrm{g} / \mathrm{l}$ (recommended) and 10.8 (SD $0.7) \mu \mathrm{g} / \mathrm{l}$ (measured, $\mathrm{N}=15$ ) for $\mathrm{U}-\mathrm{Mn}$.

\section{Statistics}

Several of the measured variables had skewed distributions. They were log-transformed if the skewness exceeded 2.0 or if the distributions to be compared had different variances as assessed by Levene's test. An analysis of variance (ANOVA) was used for the group comparisons. An analysis of covariance (ANACOVA) was used to control for the covariates.

Two stages of multiple linear regression analysis (backward procedure) were performed for studying the associations between the effect variables, exposure variables, and potential confounders. All the exposed subjects and all the referents $(\mathrm{N}=200)$ were included in the first analytical stage. Associations between the effect variables, potential confounders [smoking habits (grams/week), alcohol consumption (liters/year), and shift work] and exposure status (exposed/unexposed= $1 / 0)$ were assessed. This procedure was chosen for assessing the group differences by taking into account relevant potential confounders.

The second analytical stage included only the exposed workers and was carried out for the effect variables associated with exposure status, after control for potential confounders. The associations between the effect variables, potential confounders [smoking habits (grams/week), alcohol consumption (liters/year), and shift work] and the different exposure measures were studied. In the cases in which age was associated with the effect variables for the referents, age was also included as a potential confounder. The seven exposure measures (current B-Mn, current U-Mn, "years of manganese exposure", "inhalable manganese", "soluble inhalable manganese", "respirable manganese", "soluble respirable manganese") were entered separately into the multiple regression models in order to avoid problems of collinearity.

The statistical package SPSS ${ }^{\circledR}$, version 8.0 (SPSS Inc, Chocago, Il, USA), was used on a personal computer.

\section{Results}

The individual geometric mean manganese concentration of the inhalable aerosol fraction was 301 (range 911457) $\mu \mathrm{g} / \mathrm{m}^{3}$ (table 2). Manganese in the respirable aerosol fraction was collected for 59 subjects, the geometric mean concentration being $36 \mu \mathrm{g} / \mathrm{m}^{3}$. There was a substantial overlap in the B-Mn concentrations between the groups.

The mean concentrations of prolactin and LH (table 3) and anti-TPO (table 4) in serum were higher in the exposed subjects than in the referents. The differences were of marginal significance for $\mathrm{LH}(\mathrm{P}=0.048)$ and anti-TPO $(\mathrm{P}=0.036)$ and of borderline significance for prolactin $(\mathrm{P}=0.06)$. There was substantial overlap in the concentrations between the groups. The multiple linear regression analysis including all 200 subjects (independent variables: smoking habits, alcohol consumption, shift work and exposure status) showed that the serum concentrations of prolactin, $\mathrm{LH}$, and anti-TPO were significantly and positively associated with exposure status (not tabulated). Confounders contributing to the models at a P-value of $<0.10$ were used to adjust the estimates shown in tables 3 and 4. Smoking habits were significantly $(\mathrm{P}=0.002)$ negatively associated with serum prolactin. Age was associated with the serum concentrations of prolactin (Pearson's $r=-0.20, \mathrm{P}<0.05$ ) and LH (Pearson's r $=0.20, \mathrm{P}<0.05$ ) for the referents.

The lowest serum prolactin concentrations were measured for the smoking referents (figure 1). The difference in serum prolactin between the smokers and

Table 2. Duration of manganese exposure and concentrations of manganese (Mn) in the workroom air, whole blood (B-Mn) and urine

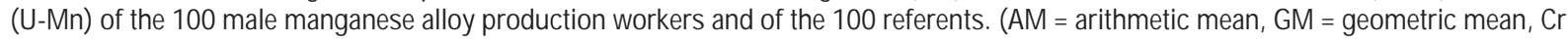
= creatinine)

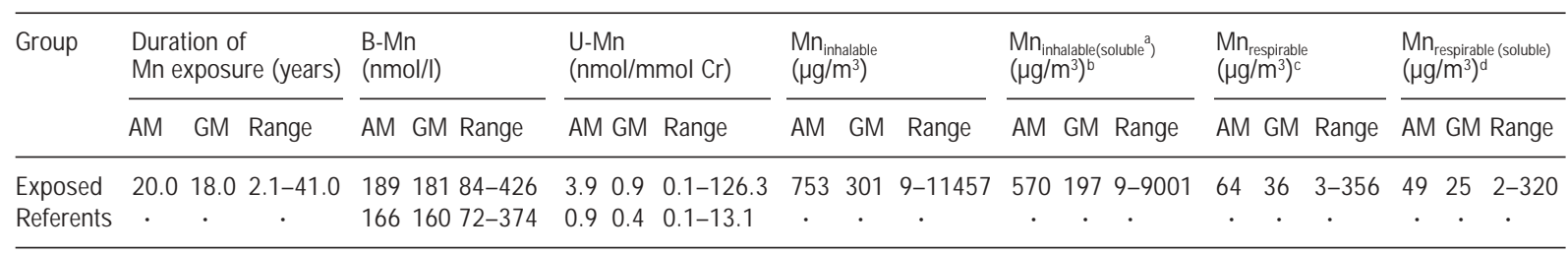

\footnotetext{
a Soluble: see the section on exposure assessment.

b $\mathrm{N}=97$ subjects.

c $\mathrm{N}=59$ subjects.

d $\mathrm{N}=53$ subjects
} 
Table 3. Endocrine marker concentrations and the mean group differences (and 95\% confidence intervals) of the measured markers for the 100 men exposed to manganese and the 100 referents. Adjusted mean group differences are shown for prolactin and luteinizing hormone (LH). Group differences between log-transformed variables are presented as ratios. (SHBG=sex hormone binding globulin, $\mathrm{GM}=$ geometric mean, $\mathrm{AM}=$ arithmetic mean)

\begin{tabular}{|c|c|c|c|c|c|c|c|c|c|c|c|c|c|}
\hline \multirow[t]{2}{*}{ Group } & \multicolumn{3}{|c|}{$\begin{array}{l}\text { Prolactin } \\
(\mathrm{mlU} / \mathrm{l})\end{array}$} & \multicolumn{3}{|c|}{$\begin{array}{l}\text { Luteinizing hormone } \\
\text { (IU/I) }\end{array}$} & \multicolumn{3}{|c|}{$\begin{array}{l}\text { Follicle stimulating } \\
\text { hormone } \\
\text { (IU/l) }\end{array}$} & \multicolumn{2}{|c|}{$\begin{array}{l}\text { Testosterone }{ }^{a} \\
(\mathrm{nmol} / \mathrm{l})\end{array}$} & \multicolumn{2}{|c|}{$\begin{array}{l}\text { SHBG } \\
(\mathrm{nmol} / \mathrm{l})\end{array}$} \\
\hline & $\mathrm{GM}$ & Range & P-value & $\mathrm{GM}$ & Range & P-value & GM & Range $P-1$ & -value & $\mathrm{AM}$ & Range P-value & $\mathrm{AM}$ & Range P-value \\
\hline Exposed & 229 & $65-1367$ & . & 4.5 & $1.5-12.4$ & . & 4.5 & $0-18.3$ & . & 15.6 & $5.0-29.3$ & 33.3 & 13-102 \\
\hline Referents & 197 & $71-842$ & $\cdot$ & 3.9 & $0.8-22.1$ & · & 4.4 & $0.5-47.3$ & . & 15.5 & $6.2-32.7$ & 31.9 & 8-104 \\
\hline Group difference & 1.16 & $0.99-1.35^{b}$ & 0.061 & 1.15 & $1.0-1.31 \mathrm{~b}$ & 0.048 & 1.04 & $0.86-1.25^{b}$ & b 0.70 & 0.2 & $-1.2-1.5^{\text {b }} 0.83$ & 1.4 & $-2.9-5.7$ b 0.53 \\
\hline Adjusted difference $^{c}$ & 1.17 & $1.01-1.36^{b}$ & 0.037 & 1.14 & $1.0-1.31^{b}$ & 0.058 & . & . & . & . & . & . & . \\
\hline
\end{tabular}

${ }^{a}$ Measured for 97 referents.

b $95 \%$ confidence interval.

${ }^{c}$ Adjusted for tobacco smoking and shift work for prolactin and for alcohol consumption for luteinizing hormone.

Table 4. Immunologic marker concentrations and the mean group differences (and 95\% confidence intervals) of the measured markers for the 100 men exposed to manganese and the 100 referents. Adjusted mean group differences are shown for antibodies to thyroid peroxidase (anti-TPO). Group differences between log-transformed variables are presented as ratios. (IL=interleukin, ANA=antinuclear antibodies, $\mathrm{GM}=$ geometric mean, $\mathrm{AM}=$ arithmetic mean)

\begin{tabular}{|c|c|c|c|c|c|c|c|c|c|c|c|c|}
\hline \multirow[t]{2}{*}{ Group } & \multicolumn{3}{|c|}{ Interferon $\gamma(\mathrm{OD} \times 1000)$} & \multicolumn{3}{|c|}{ IL-2 receptors (pg/ml) } & \multicolumn{3}{|c|}{ anti-TPO(U/ml) } & \multicolumn{3}{|c|}{ ANA (ODx 1000) } \\
\hline & $\mathrm{GM}$ & Range & P-value & $\mathrm{AM}$ & Range & P-value & $\mathrm{AM}$ & Range & P-value & GM & Range & P-value \\
\hline Exposed & 71 & $1-690$ & & 774 & $1-1860$ & . & 31.8 & $12.5-68.0$ & . & 36 & $1-640$ & 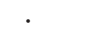 \\
\hline Referents & 71 & $1-760$ & $\cdot$ & 776 & $1-1911$ & · & 29.8 & $12.5-46.0$ & . & 33 & $1-560$ & . \\
\hline Group difference & 0.99 & $0.85-1.16^{a}$ & 0.91 & -2 & $-96-92^{a}$ & 0.97 & 2 & $0.1-3.9^{a}$ & 0.036 & 1.10 & $0.75-1.60^{a}$ & 0.63 \\
\hline Adjusted difference ${ }^{b}$ & . & . & 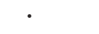 & . & . & . & 2 & $0.2-3.9^{a}$ & 0.034 & . & . & $\cdot$ \\
\hline
\end{tabular}

a $95 \%$ confidence interval.

${ }^{b}$ Adjusted for tobacco smoking for anti-TPO.

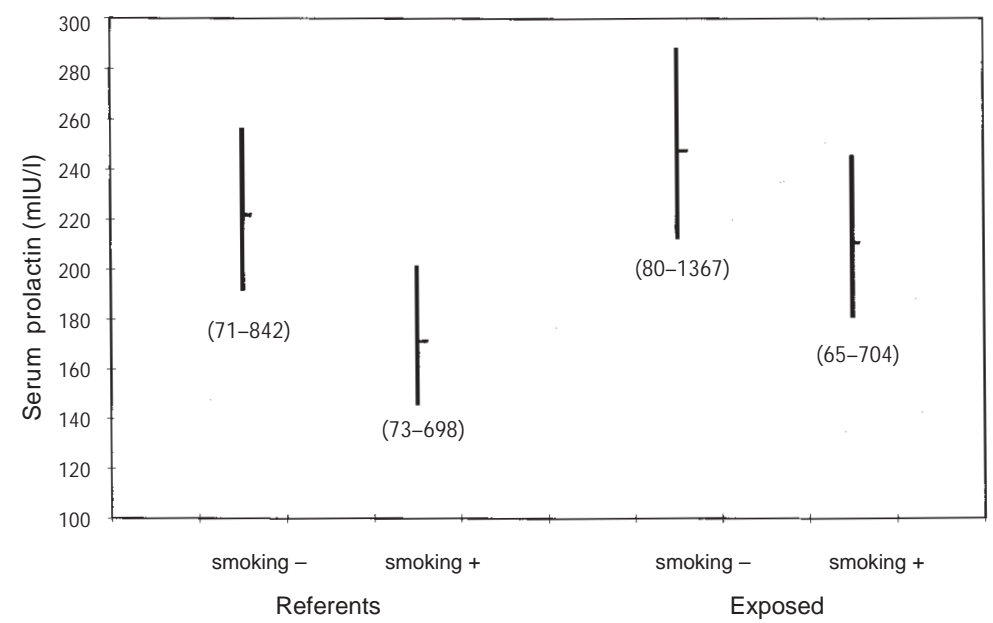

Figure 1. Concentrations (geometric means and $95 \%$ confidence intervals) of prolactin in serum (adjusted for age) from 100 referents and 100 men exposed to manganese according to smoking habits. The ranges are shown in parentheses.

nonsmokers was statistically significant for the referents $(\mathrm{P}=0.01)$, but not for the exposed subjects $(\mathrm{P}=0.16)$. The difference between the manganese-exposed subjects and the referents was of marginal statistical significance for the smokers $(\mathrm{P}=0.049)$, but not for the nonsmokers $(\mathrm{P}=0.31)$. A two-way ANOVA revealed no statistical interaction between smoking and exposure $(\mathrm{P}=0.55)$.
Only the manganese-exposed subjects were included in the multiple linear regression analysis for the further analysis of dose and prolactin, LH, and anti-TPO (table 5). The exposure measures shown in table 2 were included separately in the models. The serum prolactin concentration was positively associated with current exposure to "soluble inhalable manganese" (in milligrams per cubic meter) and with "years of manganese 
Table 5. Associations between the manganese exposure measures and the serum concentrations of prolactin and luteinizing hormone (LH) for the 100 male workers in manganese alloy production. The 95\% confidence intervals of the coefficients are shown in the superscript in parentheses. (U-Mn $=$ mangnese in urine, $\mathrm{B}-\mathrm{Mn}=$ manganese in blood serum)

\begin{tabular}{|c|c|c|}
\hline & $\alpha$ & $\mathrm{R}^{2}$ \\
\hline $\mathrm{LH}(\log )$ & $=0.66^{(0.62-0.69)}+0.05 U-\mathrm{Mn}(\log )^{(0.002-0.11)}$ & $0.04^{a}$ \\
\hline $\mathrm{LH}(\log )$ & $=0.77^{(0.65-0.89)}-0.0006 \mathrm{~B}-\mathrm{Mn}(-0.001-0)$ & $0.04^{a}$ \\
\hline Prolactin (log) & $=2.6^{(2.3-2.8)}+0.008$ exposure duration $(0.001-0.016)-0.009$ age $^{(-0.02--0.002)}$ & $0.07^{\mathrm{a}}$ \\
\hline Prolactin(log) & $=2.4^{(2.3-2.5)}+0.08$ "soluble inhalable manganese" $(\log )^{(0.01-0.17)}$ & $0.05^{\mathrm{a}}$ \\
\hline
\end{tabular}

a $P<0.05$

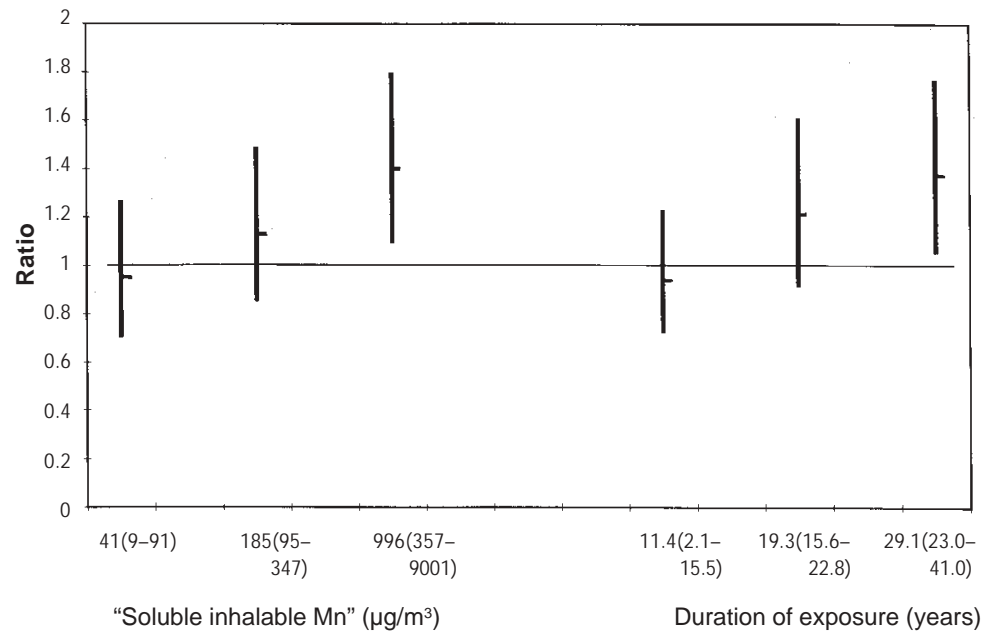

Figure 2. Ratio of prolactin (and $95 \%$ confidence intervals) between the men exposed to manganese and the corresponding pairwise age-matched referents (adjusted for age and smoking). The left panel shows the subjects stratified according to their current exposure (geometric mean and range in micrograms per cubic meter) to "soluble inhalable manganese" into "low", "medium", and "high" exposure. The right panel shows the results stratified according to exposure duration in years (mean and range) into "few", "medium", "many" years.

exposure". Smoking habits were of borderline significance. LH was associated positively with the U-Mn and negatively with the B-Mn concentrations. Anti-TPO was not associated with any of the exposure measures. In a final approach "soluble inhalable manganese" and "years of manganese exposure" were included in one model: prolactin $(\log )=2.66^{(2.41-2.92)}+0.008^{(0.001-0.016)}$ exposure duration $+0.095^{(0.018-0.172)}$ "soluble inhalable manganese" (log)-0.009 ${ }^{\left(-0.016-{ }^{-0.002)}\right.}$ age; $\mathrm{R}^{2}=0.12$, $\mathrm{P}=0.008$. The U-Mn(log) and B-Mn were statistically significantly included in a model to predict LH when entered simultaneously, however, in opposite directions: $\mathrm{LH}(\log )=0.80^{(0.69-0.92)}+0.067^{(0.015-0.118)} \mathrm{U}-\mathrm{Mn}(\log )-$ $0.0008^{(-0.001-0.000)} \mathrm{B}-\mathrm{Mn} ;\left(\mathrm{R}^{2}=0.10, \mathrm{P}=0.005\right)$. The $95 \%$ confidence intervals $(95 \% \mathrm{CI})$ are shown in the superscripts in parentheses.

The age-matched paired study design was chosen to perform the stratified analysis with respect to the exposure measures of interest. The exposed subjects in each stratum were compared with their respective agematched referents. Having a longer duration of exposure or being exposed currently to higher concentrations of "soluble inhalable manganese" resulted in higher serum prolactin concentrations when compared with those of their age-matched referents (figure 2). The differences were significant in the stratum with the longest exposure duration $(\mathrm{P}=0.017)$ or in that with the highest concentrations of "soluble inhalable manganese" $(\mathrm{P}=0.008)$. The group differences of the concentrations have been expressed as ratios because prolactin was logtransformed.

The stratification of the exposure duration was maintained for the further study of the relationships between serum prolactin, exposure duration, and exposure to "soluble inhalable manganese". "Soluble inhalable manganese" was split according to the median into "low" and "high" (cut point $187 \mu \mathrm{g} / \mathrm{m}^{3}$ ). The subjects exposed short-term to "high" "soluble inhalable manganese" concentrations had serum prolactin concentrations that were comparable with those of their age-matched referents (table 6). The subjects exposed long-term to approximately the same concentrations of "soluble inhalable manganese" had a significantly higher ratio of prolactin than their age-matched referents (ratio 1.46, 95\% CI 1.04-2.05). Figure 3 shows the geometric mean and $95 \%$ confidence intervals for the serum prolactin concentrations (adjusted for age and smoking habits) in the same strata as in table 6, but the referents in each stratum have been merged into one group. The highest serum prolactin concentrations were found among the long-term "highly" exposed subjects.

The serum prolactin concentrations were generally within the normal laboratory range. The values of three referents and four exposed subjects exceeded the upper 
Table 6. Ratio of prolactin and the $95 \%$ confidence intervals (95\% C) (adjusted according to smoking habits) between the subjects exposed to manganese $(\mathrm{Mn})$ and the corresponding age-matched referents. The exposed subjects were stratified into three groups according to the duration of exposure (in years) and further into "low" or "high" current exposure to "soluble inhalable manganese"(cut point $\left.187 \mu \mathrm{g} / \mathrm{m}^{3}\right)$. ( $\mathrm{AM}=$ arithmetic mean, $\mathrm{GM}$ = geometric mean)

\begin{tabular}{|c|c|c|c|c|c|c|c|c|c|c|}
\hline & & & \multicolumn{4}{|c|}{ Age (years) } & & & & \\
\hline & \multicolumn{2}{|c|}{ Prolactin } & \multicolumn{2}{|c|}{ Exposed } & \multicolumn{2}{|c|}{ Referents } & \multicolumn{2}{|c|}{$\mathrm{Mn}_{\text {inhalable(soluble) }}$} & \multicolumn{2}{|c|}{$\begin{array}{l}\text { Duration of exposure } \\
\text { (years) }\end{array}$} \\
\hline & Ratio & $95 \% \mathrm{Cl}$ & $\mathrm{AM}$ & Range & $\mathrm{AM}$ & Range & $\mathrm{GM}$ & Range & $A M$ & Range \\
\hline \multicolumn{11}{|c|}{ Short-term exposure } \\
\hline Low $(\mathrm{N}=18)$ & 0.86 & $0.61-1.23$ & 38.9 & $27.6-58.5$ & 38.9 & $27.7-59.4$ & 57 & $13-167$ & 11.9 & $3.0-15.5$ \\
\hline High $(\mathrm{N}=15)$ & 1.05 & $0.70-1.58$ & 37.3 & $29.3-54.5$ & 37.7 & $29.4-55.1$ & 617 & $187-2262$ & 10.8 & $2.1-15.3$ \\
\hline \multicolumn{11}{|c|}{ Medium-term exposure } \\
\hline Low $(\mathrm{N}=15)$ & 1.04 & $0.64-1.71$ & 43.1 & $32.7-59.9$ & 42.8 & $32.7-56.8$ & 67 & $21-154$ & 19.8 & $16.1-22.8$ \\
\hline High $(\mathrm{N}=17)$ & 1.38 & $0.95-1.99$ & 44.6 & $32.6-61.9$ & 44.6 & $32.8-61.3$ & 584 & 199-9001 & 19.1 & $15.6-22.7$ \\
\hline \multicolumn{11}{|c|}{ Long-term exposure } \\
\hline Low $(\mathrm{N}=15)$ & 1.31 & $0.90-1.90$ & 52.3 & $41.1-61.0$ & 52.4 & $41.1-61.4$ & 60 & $9-179$ & 31.0 & $23.1-41.0$ \\
\hline High $(\mathrm{N}=17)$ & 1.46 & $1.04-2.05$ & 49.1 & $41.5-59.6$ & 49.0 & $41.9-59.4$ & 676 & $222-5162$ & 27.5 & $23.0-39.2$ \\
\hline
\end{tabular}

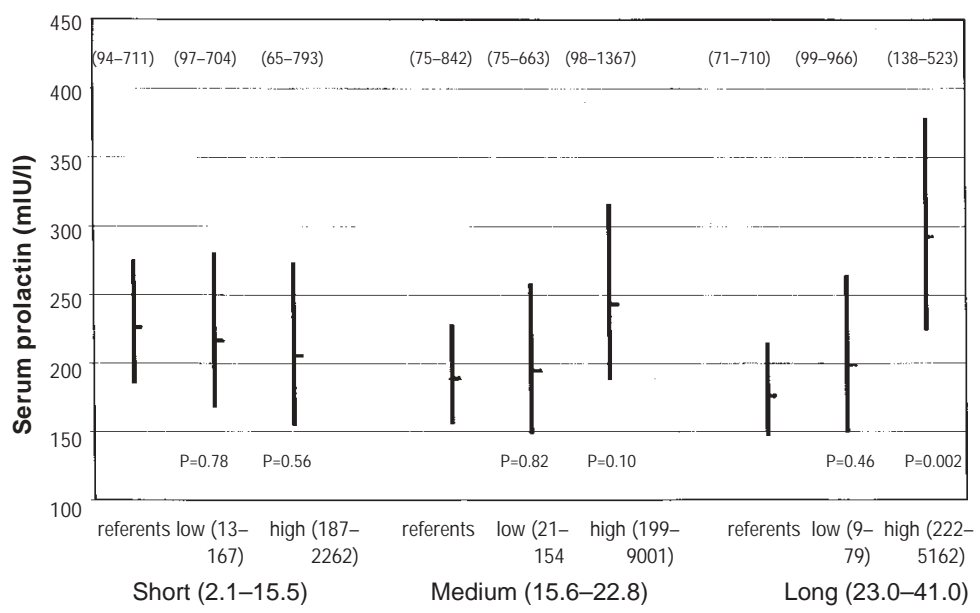

Figure 3. Geometric mean concentrations (and 95\% confidence intervals) for serum prolactin from the exposed subjects stratified according to the exposure duration (short, medium, and long) and current exposure to "solubleinhalable manganese (high and low). The ranges of theair concentrations, durations, and serum prolactin concentrations are shown in parentheses. The P-values were calculated by comparing the referents in each stratum with the respective two exposed groups.

reference value $(700 \mathrm{mIu} / \mathrm{l})$. Six exposed subjects exceeded the 95th percentile in the reference group (cut point $610 \mathrm{mIu} / \mathrm{l})$.

\section{Discussion}

This study focused on selected hormones and immunologic markers in the serum of manganese alloy production workers exposed to a mixture of manganese compounds. The personal current exposure in the inhalable aerosol fraction had a geometric mean of $301 \mu \mathrm{g} \mathrm{Mn} / \mathrm{m}^{3}$. The high participation rates ( $90.9 \%$ in both groups) suggest that selection bias was of minor importance. The long mean exposure of 20 years suggests a low turnover rate among the exposed subjects. However, it cannot be excluded that subjects became ill due to exposure and thus were not available for inclusion. This possibility could have resulted in an underestimation of the effect. The exposed subjects and the referents were comparable with respect to age, alcohol consumption, prevalence of shift work, smoking habits, and their work in similar industries. The concentrations of U-Mn and B-Mn were compatible with those of other studies. We have no explanation for the relatively high upper ranges of the U-Mn concentrations in both groups. In an attempt to avoid contamination, the samples were voided at home, and there were no indications of external contamination in the laboratory analysis.

The slightly higher mean concentration of prolactin in the serum of the exposed subjects than in the referents was the core finding of our study. The concentration was associated with the duration of manganese exposure and the current individual exposure to "soluble inhalable manganese". This finding has previously not been shown. Higher serum prolactin concentrations in manganese-exposed current smokers, compared with currently smoking referents, has never been observed before. The difference did not attain statistical 
significance for the nonsmokers. A two-way ANOVA analysis did not reveal a statistical interaction between smoking habits and exposure status.

The slightly higher concentrations of LH in the exposed workers were contradictorily associated with exposure measures, the finding suggesting high B-Mn to be associated with low serum LH and high U-Mn to be associated with high serum LH. Hence, the results do not, in our opinion, provide enough evidence to suggest that exposure to manganese influences the serum concentration of LH. It has, however, been described that an increased serum prolactin concentration may result in increased central dopaminergic tone, which could result in a loss of LH pulsatility (20). This possibility suggests that sufficiently high exposure may alter LH.

Anti-TPO was higher in the exposed workers, but no relation to any exposure measure was found. The question of whether high concentrations of circulating prolactin in manganese-exposed subjects may induce the production of anti-TPO and perhaps result in autoimmune thyroid disease (10) remains to be elucidated. Interferon- $\gamma$ and IL-2 receptors are both related to the defense against infectious diseases. The serum concentrations of these markers were remarkably similar in the two groups.

The plasma prolactin concentration is mainly regulated by dopamine exerting a tonic inhibition on prolactin release. Dopaminergic neurons run from the hypothalamus to the portal vessels of the median eminence of the pituitary stalk. The median eminence, the pituitary stalk, and the pituitary, including the lactotrope cells with the $\mathrm{D}_{2}$ receptors on their surface, are not protected by the blood-brain barrier. This area may consequently constitute a vulnerable target for manganese toxicity. Retrograde axonal transport of manganese into the hypothalamic dopaminergic neurons, which in turn could perhaps lead to neuronal destruction, cannot be excluded as an alternative possible toxicologic mechanism.

With this background, it is interesting to note that the serum prolactin concentration of the exposed subjects increased as current exposure to "soluble inhalable manganese" increased. "Soluble inhalable manganese" includes all the manganese compounds found in this industry except the extremely little soluble silicomanganese. When "inhalable manganese" (including silicomanganese) was used as a marker of exposure, no association with serum prolactin was found. This finding has previously not been shown. The results also suggest that some kind of cumulative exposure, in our study expressed as "years of exposure to manganese", is also involved in the process of increasing the serum prolactin concentration. As shown in table 6 and figure 3, similar current exposure to "soluble inhalable manganese" had a different impact on the serum prolactin concentration depending on the duration of exposure in years. This finding could indicate a mechanism suggesting a slow destruction of sensitive tissues, which has been so small that additional current exposure may be necessary to reveal an effect. Our results are compatible with the observation that manganese-exposed workers from similar plants in Italy showed an increase in their serum prolactin concentrations during a 5-year period of exposure (21). It is, however, important to emphasize that the changes found in our study are small. An equal, and small, number of subjects in the exposed $(\mathrm{N}=4)$ and the reference $(\mathrm{N}=3)$ groups exceeded the upper reference limit of the laboratory. This finding suggests that there is no clinical significance in the increased prolactin concentrations at this exposure level and that serum prolactin is not suitable as a screening tool on an individual basis at this level of exposure.

The following three independent environmental factors appear to be of importance for the results: "years of exposure to manganese", which may represent an indication of cumulative exposure; current exposure to "soluble inhalable manganese"; and current smoking habits. When the smoking habits are considered, the results suggest that a current exposure equaling a geometric mean of 996 (range 357-9001) $\mu \mathrm{g} / \mathrm{m}^{3}$ (95\% CI 7401339) to "soluble inhalable manganese" results in increased serum prolactin concentrations. The corresponding geometric mean concentration of "inhalable manganese" is 1270 (range 386-11 457) $\mu \mathrm{g} / \mathrm{m}^{3}$ (95\% CI 9441711). Between $10 \%$ and $11 \%$ of the manganese was found in the respirable aerosol fraction (18). These estimates do not consider the impact of exposure duration on the measured serum prolactin concentrations. The workers were probably exposed previously to higher amounts of manganese. One study has suggested a reduction in the manganese concentrations from approximately $1.5 \mathrm{mg} / \mathrm{m}^{3}$ (median) in 1979 to around $0.5 \mathrm{mg} /$ $\mathrm{m}^{3}$ (median) in 1990 ("total manganese") in the plant from which half of the population of our study was recruited (22). Whether the higher exposure occurring previously is a prerequisite for the induction of the demonstrated effect on serum prolactin concentration, or lower long-term exposure is sufficient, could not be determined in our study.

Increased serum prolactin in association with manganese exposure has been shown previously $(4,5)$. However, the studies did not take into account the impact of smoking habits on the serum prolactin concentrations, as we did. It appears that smoking and manganese have an opposite effect on the serum prolactin concentration. A depressive effect of nicotine on serum prolactin concentration has been shown (23). It appears that chronic nicotine administration suppresses the pituitary prolactin secretion by increasing hypothalamic 
tuberoinfundibular dopaminergic activity (24). The nicotine-induced reduction of the serum prolactin concentration was reversible in male Sprague-Dawley rats, the concentration being normalized between day 3 and day 7 postexposure (24). This knowledge has some implications with respect to epidemiologic research. Nicotine acts in the region in which one can assume that also manganese could act with respect to the serum prolactin concentration. Smoking habits could act as an important confounder in epidemiologic studies using serum prolactin as a biomarker, when not properly taken into account, and could result in either an overestimation or underestimation of the effects attributable to manganese exposure, depending on the differences in the smoking habits of the groups to be compared. It may also be that changes in smoking patterns over time may introduce a possible bias in epidemiologic prolactin studies. We found no literature dealing with co-exposure to manganese and tobacco smoke and the effects on the serum prolactin concentration in humans.

\section{Acknowledgments}

We acknowledge the cooperation with the participating plants (Elkem ASA, Tinfos Jernverk AS and Eramet Norway) and their workforces. Erle Grieg-Astrup (PhD) at Elkem ASA introduced us to the manganese alloy producing industry in Norway. Gunhild Sand and Elaine Nilsen carried out the manganese measurements.

The study was financially supported by the Work Environment Fund of the Norwegian Business Association, Elkem AS, Tinfos Jernverk AS, and Eramet Norway.

\section{References}

1. Verity MN. Manganese neurotoxicity: a mechanistic hypothesis. Neurotoxicology 1999;20:489-98.

2. Thorner MO, Vance ML, Horvath E, Kovacs K. The anterior pituitary. In: Wilson JD, Foster DW, editors. Williams textbook of endocrinology. 8th ed. Philadelphia (PA): WB Saunders Company; 1992;221-310.

3. Barbeau A, Inoué N, Cloutier T. Role of manganese in dystonia. In: Eldridge R, Fahn S, editors. Advances in neurology, vol 14. New York (NY): Raven Press; 1976;339-52.

4. Alessio L, Apostoli P, Ferioli A, Lombardi S. Interference of manganese on neuroendocrinal system in exposed workers. Biol Trace Elem Res 1989;21:249-53.

5. Mutti A, Bergamaschi E, Alinovi R, Lucchini R, Vittori MV,
Franchini I. Serum prolactin in subjects occupationally exposed to manganese. Ann Clin Lab Sci 1996;26:10-7.

6. Roels HA, Ghyselen P, Buchet JP, Lauwerys RR. Assessment of permissible exposure level to manganese in workers exposed to manganese dioxide dust. Br J Ind Med 1992;49:25-34.

7. Rodier J. Manganese poisoning in Morroccan miners. Br J Ind Med 1955;12:21-35.

8. Draca S. Prolactin as an immunoreactive agent. Immunol Cell Biol 1995;73:481-3.

9. Berczi I, Chalmers I, Nagy E, Warrington RJ. The immune effects of neuropeptides. Baillieres Clin Rheumatol 1996;10:227-57.

10. Weigent DA. Immunoregulatory properties of growth hormone and prolactin. Pharmacol Ther 1996;69:237-57.

11. Matera L. Endocrine, paracrine and autocrine actions of prolactin on immune cells. Life Sci 1996;59:599-614.

12. Srisuchart B, Taylor MJ, Sharma RP. Alteration of humoral and cellular immunity in manganese chloride-treated mice. J Toxicol Environ Health 1987;22:91-9.

13. Rogers RR, Garner RJ, Riddle MM, Luebke RW, Smialowicz RJ. Augmentation of murine natural killer cell activity by manganese chloride. Toxicol Appl Pharmacol 1983;70:7-17.

14. Smialowicz RJ, Rogers RR, Riddle MM, Luebke RW, Fogelson LD. Effects of manganese, calcium, magnesium, and zinc on nickel-induced suppression of murine natural killer cell activity. J Toxicol Environ Health 1987;20:67-80.

15. Smialowicz RJ, Luebke RW, Rogers RR, Riddle MM, Rowe DG. Manganese chloride enhances natural cell-mediated immune effector cell function: effects on macrophages. Immunopharmacology 1985;9:1-11.

16. Hahon N, Booth JA. Effect of chromium and manganese particles on the interferon system. J Interferon Res 1984;4:1727.

17. Hauge R, Irgens-Jensen O. Alkoholen i Norden [Alcohol in the Nordic countries]. Alkoholpolitik 1987;4 Suppl:48-9.

18. Ellingsen DG, Hetland SM, Thomassen Y. Manganese air exposure and biological monitoring in the manganese alloy production industry. J Environ Monit 2003;5:84-90.

19. Thomassen Y, Ellingsen DG, Hetland S, Sand G. Chemical speciation-Sequential extraction of manganese in work room aerosols: analytical methodology and results from a field study in manganese alloy plants. J Environ Monit 2001;3:555-9.

20. Benker G, Jaspers C, Häusler G, Reinwein D. Control of prolactin secretion. Klin Wochenschr 1990;68:1157-67.

21. Smargiassi A, Mutti A. Peripheral biomarkers and exposure to manganese. Neurotoxicology 1999;20:401-6.

22. Hobbesland $\AA$, Kjuus H, Thelle DS. Mortality from cardiovascular diseases and sudden death in ferroalloy plants. Scand J Work Environ Health 1997;23:334-41.

23. Fuxe K, Andersson K, Eneroth P, Härfstrand A, Agnati LF. Neuroendocrine actions of nicotine and of exposure to cigarette smoke: medical implications. Psychoneuroendocrinology 1989;14:19-41.

24. Rasmussen DD. Effects of chronic nicotine treatment and withdrawal on hypothalamic proopiomelanocortin gene expression and neuroendocrine regulation. Psychoneuroendocrinology 1998;23:245-59.

Received for publication: 19 August 2002. 